Abstracta Iranica Abstracta Iranica

Revue bibliographique pour le domaine irano-aryen

Volume 32-33 | 2013

Comptes rendus des publications de 2009-2010

\title{
Beatrice Teissier. Texts from the Persian in Late Eighteenth-century India and Britain: Culture or Construct
}

\section{Fabrizio Speziale}

\section{(2) OpenEdition \\ 1 Journals}

\section{Édition électronique}

URL : http://journals.openedition.org/abstractairanica/40642

DOI : 10.4000/abstractairanica.40642

ISSN : 1961-960X

Éditeur :

CNRS (UMR 7528 Mondes iraniens et indiens), Éditions de l'IFRI

\section{Édition imprimée}

Date de publication : 1 décembre 2013

ISSN : 0240-8910

\section{Référence électronique}

Fabrizio Speziale, «Beatrice Teissier. Texts from the Persian in Late Eighteenth-century India and Britain: Culture or Construct », Abstracta Iranica [En ligne], Volume 32-33 | 2013, document 283, mis en ligne le 01 juillet 2016, consulté le 03 octobre 2020. URL : http://journals.openedition.org/abstractairanica/ 40642 ; DOI : https://doi.org/10.4000/abstractairanica.40642

Ce document a été généré automatiquement le 3 octobre 2020.

Tous droits réservés 


\title{
Beatrice Teissier. Texts from the Persian in Late Eighteenth-century India and Britain: Culture or Construct
}

\author{
Fabrizio Speziale
}

\section{RÉFÉRENCE}

Beatrice Teissier. « Texts from the Persian in Late Eighteenth-century India and Britain: Culture or Construct ». IRAN, XLVII, p. 133-147.

1 Cet article analyse les activités des orientalistes qui opérèrent en Inde, visant à produire des éditions - ainsi que des traductions en anglais - de textes en persan, qui demeura la langue officielle de l'administration britannique en Inde jusqu'à 1835. L'A. examine notamment les textes à caractère historique qui furent édités et traduits jusqu'à la fin du XVIII ${ }^{e}$ s., et analyse certaines des figures principales de ce courant d'études ainsi que leur interprétation et utilisation de ces sources persanes.

\section{AUTEURS}

\section{FABRIZIO SPEZIALE}

Université Sorbonne Nouvelle-Paris 3/Mondes iranien et indien, Paris 